\title{
A new species of Scytinopogon from the island of Príncipe, Republic of São Tomé and Príncipe, West Africa
}

\section{Desjardin $\mathrm{DE}^{1}$ and Perry $\mathrm{BA}^{2}$}

${ }^{1}$ Department of Biology, San Francisco State University, 1600 Holloway Ave., San Francisco, California 94132, USA; ded@sfsu.edu

${ }^{2}$ Department of Biological Sciences, California State University East Bay, 25800 Carlos Bee Blvd., Hayward, California 94542,USA; brian.perry@csueastbay.edu

Desjardin DE, Perry BA 2015 - A new species of Scytinopogon from the island of Príncipe, Republic of São Tomé and Príncipe, West Africa. Mycosphere 6(4), 434-441, Doi 10.5943/mycosphere/6/4/5

\begin{abstract}
Scytinopogon havencampii is described as new from material collected from a nonectotrophic forest on the West African island of Príncipe. Diagnostic features include brown, nonflattened branches with white tips, small, white, ellipsoid, coarsely echinate basidiospores, 2-spored basidia, non-inflated hyphae, and brittle basidiomes that dry grayish white. Phylogenetic analyses of nLSU sequence data confirm placement of this new taxon within the Trechisporales. A comprehensive description, photograph of basidiome, SEM of basidiospores, DNA sequences, and comparisons with phenetically similar taxa are provided.
\end{abstract}

Key words - coral fungi - Gulf of Guinea - systematics - taxonomy - Trechisporales

\section{Introduction}

The west African islands of São Tomé and Príncipe, lying along the magmatic Cameroon Volcanic Line (aka Guinea Line) in the Gulf of Guinea, are oceanic islands in the sense of Carlquist (1965), arising from a volcanic plume and never connected to the African continent. São Tomé at 13+ my and Príncipe at 31+ my (Lee et al. 1994) are biodiversity hotspots with high levels of endemism (MacArthur \& Wilson 1967); in 2013, the island of Príncipe was designated a UNESCO World Biosphere Reserve. In April 2006 (2 wk) and April 2008 (3 wk), expeditions led by scientists from the California Academy of Sciences and joined by mycologists from San Francisco State University visited São Tomé and Príncipe to document the diversity of plants, amphibians, marine invertebrates and macrofungi. A first account of the macrofungi collected during these expeditions was the publication of a new stinkhorn, Phallus drewesii Desjardin \& B.A. Perry, from São Tomé (Desjardin \& Perry 2009). We continue reporting interesting species from the island nation with the description of a new coralloid homobasidiomycete from the oldest of the islands, Príncipe.

The earliest reports of fleshy macrofungi from São Tomé and Príncipe were by Bresadola and Roumeguère (1890), describing collections made by Moller, Quintas and Newton in 1885. Although the majority of species they reported were polypores, a few agarics, gasteromycetes, stereoid fungi, jelly fungi, ascomycetes and myxomycetes were included. Pertinent to this paper, was the description of three new coralloid homobasidiomycetes, viz., Clavaria henriquesii Bres. \& 
Roum., Lachnocladium mollerianum Bres. \& Roum., and Pterula subaquatica Bres. \& Roum. Since then, African coralloid fungi have received little attention. Corner (1950, 1966, 1970) and others (Roberts 1999, Douanla-Meli 2007) reported a number of species from mainland Africa, but the only taxa reported from São Tomé and Príncipe are the former three species, treated by Corner (1950) as Ramaria henriquesii (Bres. \& Roum.) Corner, Ramaria molleriana (Bres. \& Roum.) Corner, and Pterulicium xylogenum (Berk. \& Broome) Corner, respectively. Among the interesting species collected from a non-ectotrophic forest on Príncipe in 2008, was a brown, white-tipped Scytinopogon with small, coarsely echinate spores formed on 2-spored basidia, described as new herein.

\section{Materials \& Methods}

Specimens were dried on a Nesco food dehydrator, packed in airtight plastic bags and hand carried back to the US. Macromorphological data were derived from fresh specimens, whereas micromorphological data were derived from dried specimens rehydrated in ethanol followed by distilled water, $3 \% \mathrm{KOH}$ or Melzer's reagent. Color terms and notations are those of Kornerup and Wanscher (1978). Spore statistics include $\mathrm{x}_{\mathrm{m}}$, the arithmetic mean of the spore length by spore width ( \pm standard deviation); $\mathrm{Q}$, the quotient of spore length by spore width in any one spore, indicated as a range in variation in $\mathrm{n}$ spores measured; $\mathrm{Q}_{\mathrm{m}}$, the mean of $\mathrm{Q}$-values $( \pm$ standard deviation). For the micrographs of basidiospores, a small portion of dried hymenial tissue was mounted on an aluminum stub using graphite paint, coated with $8 \mathrm{~nm}$ of iridium in a Cressington 208HR sputter coater, and examined at an accelerating voltage of $2 \mathrm{keV}$ in a Carl Zeiss Ultra 55 field emission scanning electron microscope (FE-SEM).

Total genomic DNA was extracted from dried material using the E.Z.N.A. Forensic DNA Kit (Omega Bio-Tek, Inc., Norcross, GA) following the manufacturer's instructions. PCR and cycle sequencing protocols followed those outlined in Perry et al (2007). The nuclear ribosomal large subunit (nLSU) and internal transcribed spacer region (ITS) were symmetrically amplified using primers LROR/LR7 (Moncalvo et al. 2000) and ITS1-F/ITS4 (Gardes and Bruns 1993; White et al. 1990), respectively. Amplification products were cleaned using the Exo-SAPit kit (Affymetrix, Santa Clara, CA), and sent to ELIM Biopharmaceuticals (Hayward, CA) for sequencing. Resulting sequence fragments were edited and assembled in Geneious 8 (Biomatters Limited, Auckland, New Zealand). ClustalW (Larkin et al. 2007) and Mesquite (Maddison \& Maddison 2015) were used to align the nLSU sequence of Scytinopogon havencampii within a broader sampling of the Trechisporales as sampled in Birkebak et al. (2013) and Telleria et al. (2013). The nLSU and ITS sequences of Scytinopogon havencampii have been deposited in GenBank (nLSU-KT253947, ITS-KT253946), and the aligned nLSU dataset and associated tree file have been deposited in TreeBASE (submission \#17611).

Maximum likelihood analyses were conducted in RAxML 8.1.11 (Stamatakis 2014) under the GTRCAT model using the default parameters and run on the CIPRES Science Gateway (Miller et al. 2010), with node support assessed by 1000 RAxML bootstrap (BS) replicates. Bayesian analyses were performed using Metropolis Coupled MCMC methods as implemented in MrBayes 3.2.3 (Ronquist et al. 2012) under a GTR $+\mathrm{I}+\mathrm{G}$ model of sequence evolution as determined under the Bayesian Information Criterion in jModelTest 2.1.6 (Darriba et al. 2012, Guindon \& Gascuel 2003). Bayesian analyses consisted of two parallel searches, run for 8 million generations on the CIPRES Science Gateway, and initiated with random starting trees. Six chains were sampled every 800 generations for a total of 10,000 trees each, sampled from the posterior distribution. Those topologies sampled prior the runs reaching a split deviation frequency of 0.01 were discarded, while the remaining were used to calculate the posterior probabilities of the individual clades. The default settings were used in MrBayes to set unconstrained branch lengths and uninformative topology priors.

Based upon the maximum likelihood results, constrained topology analyses were conducted to evaluate the significance of alternative tree topologies in which the genus Trechispora was constrained to monophyly. A constrained topology was manually specified in GARLI 0.951(Zwick1 
2006) and a tree search was performed under a GTR+I+G model of sequence evolution with all parameters estimated by the program. The resulting topology was compared with the most likely, unconstrained topology using the Shimodaira \& Hasegawa (1999) test as implemented in PAUP* (Swofford 2003), with the resampling estimated log-likelihood (RELL) method and 1K BS replicates.

\section{Taxonomy}

Scytinopogon havencampii Desjardin \& B.A. Perry, sp. nov.

Figs. 1-2

Mycobank number: MB 813054

Facesoffungi number: FoF 00891

Diagnosis - Basidiome coralloid, 90-100 mm tall $\times 60-70 \mathrm{~mm}$ broad. Stipe 20-25 × 5-6 $\mathrm{mm}$, confluent, white to pale orangish white. Branches 3-4 mm diam, round in cross-section, pale brownish orange at the base grading upwards to 1-2 mm diam, grayish brown to brown with white acute tips; tissues unchanging where cut or bruised; texture rather brittle. Basidiospores 5.2-6.5 (7) $\times$ 3.5-4.2 $\mu \mathrm{m}$, ellipsoid, coarsely echinate, spines $0.5-1 \mathrm{~mm}$ tall, hyaline in $3 \% \mathrm{KOH}$, presumably white in deposit. Basidia primarily 2-spored, clamped. Hymenial cystidia absent. Hyphae 3-8 $\mu \mathrm{m}$ diam, thin-walled, clamped but not at every septum. Scattered in soil in secondary forest of non-ectotrophic trees. Holotype: Africa, Príncipe, Roça Pico Papagaio, 21 April 2008, D.E. Desjardin DED8300 (SFSU).

Etymology - Named in honor of several generous gentlemen from Haven Camp, California, who graciously provided partial support for this research.

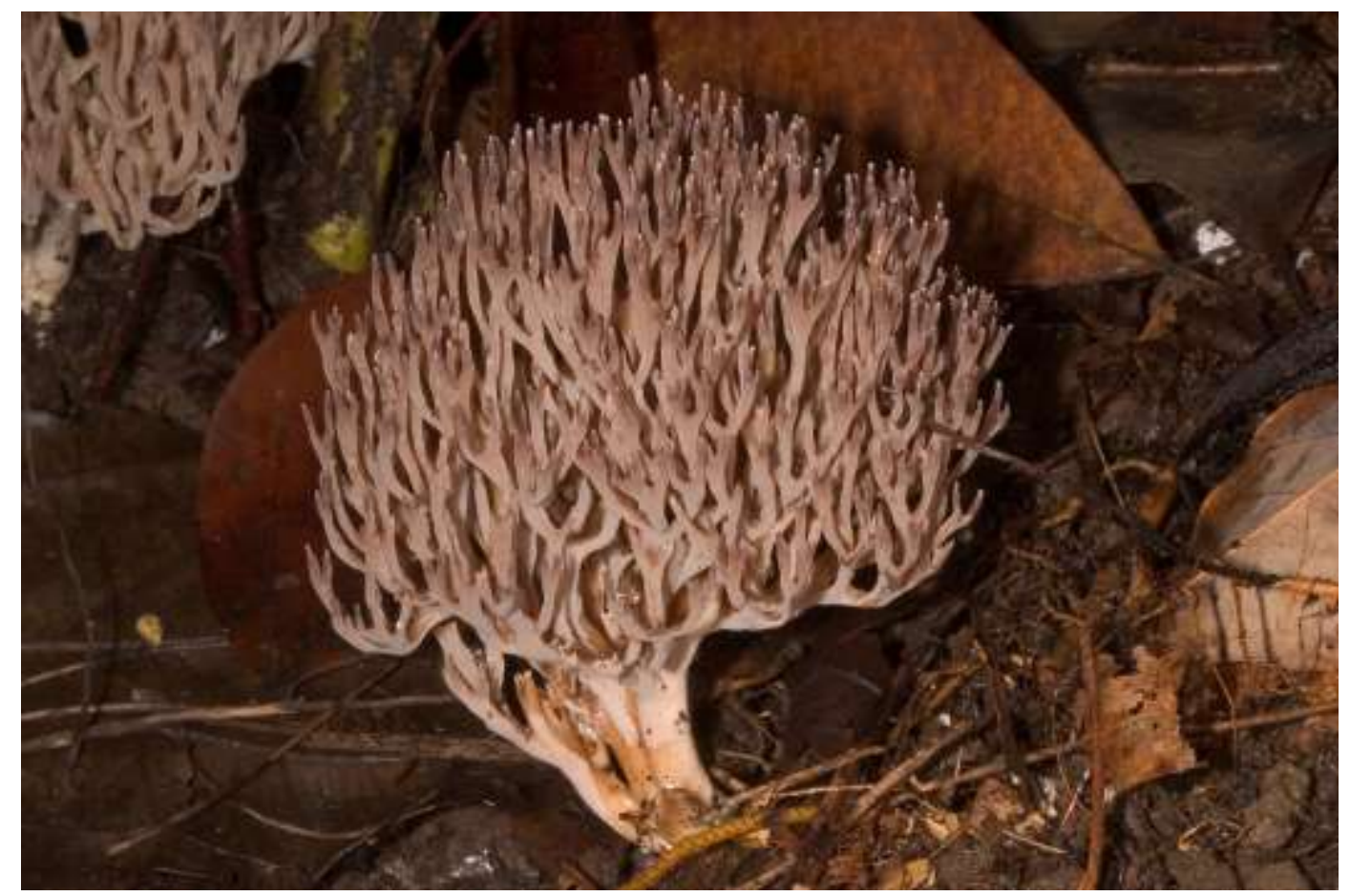

Fig. 1 - Basidiome of Scytinopogon havencampii (DED8300). Natural size.

Basidiome coralloid, 90-100 $\mathrm{mm}$ tall $\times 60-80 \mathrm{~mm}$ broad, moderately open, densely branched. Stipe 20-25 $\times 5-6 \mathrm{~mm}$, confluent, solid, white to pale orangish white (5A2). Primary lower branches 3-4 mm diam, pale brownish orange (6C3) to dingy tan; secondary branches 2-3 $\mathrm{mm}$ diam, grayish brown (7D3), axils V-shaped; tertiary and terminal branches 1-2 $\mathrm{mm}$ diam, dichotomous or rarely trichotomously branched, axils V-shaped, brown (7E3) with a hint of violet; tips acute, white. All tissue unchanging where cut or bruised; texture rather brittle. Odor not distinctive. Dried grayish white. 
Basidiospores 5.2-6.5 (-7) $\times 3.5-4.2 \mu \mathrm{m}\left[\mathrm{x}_{\mathrm{m}}=6.1 \pm 0.4 \times 3.8 \pm 0.2 \mu \mathrm{m}, \mathrm{Q}=1.5-1.7, \mathrm{Q}_{\mathrm{m}}=\right.$ $1.6 \pm 0.04, \mathrm{n}=25, \mathrm{~s}=1]$, ellipsoid, coarsely echinate, spines $0.5-1 \mathrm{~mm}$ tall, conical, hyaline in $3 \%$ $\mathrm{KOH}$, presumably white in deposit. Basidia primarily 2-spored, rarely 3- or 4-spored, 19-23 $\times 5.7-$ $8.5 \mu \mathrm{m}$ with sterigmata 5-9.5 $\mu \mathrm{m}$ long, clavate, hyaline, not golden-refringent, clamped. Hyphae 3$8 \mu \mathrm{m}$ diam, cylindrical, hyaline, smooth, thin-walled, clamped but not at every septum.

Habitat and known distribution - Scattered in soil in secondary forest of non-ectotrophic trees. Príncipe, Africa.

Material examined - Africa, Príncipe island, Roça Pico Papagaio, N0137.182', E07²3.474', 21 April 2008, collected by D.E. Desjardin, DED8300 (Holotype - SFSU).

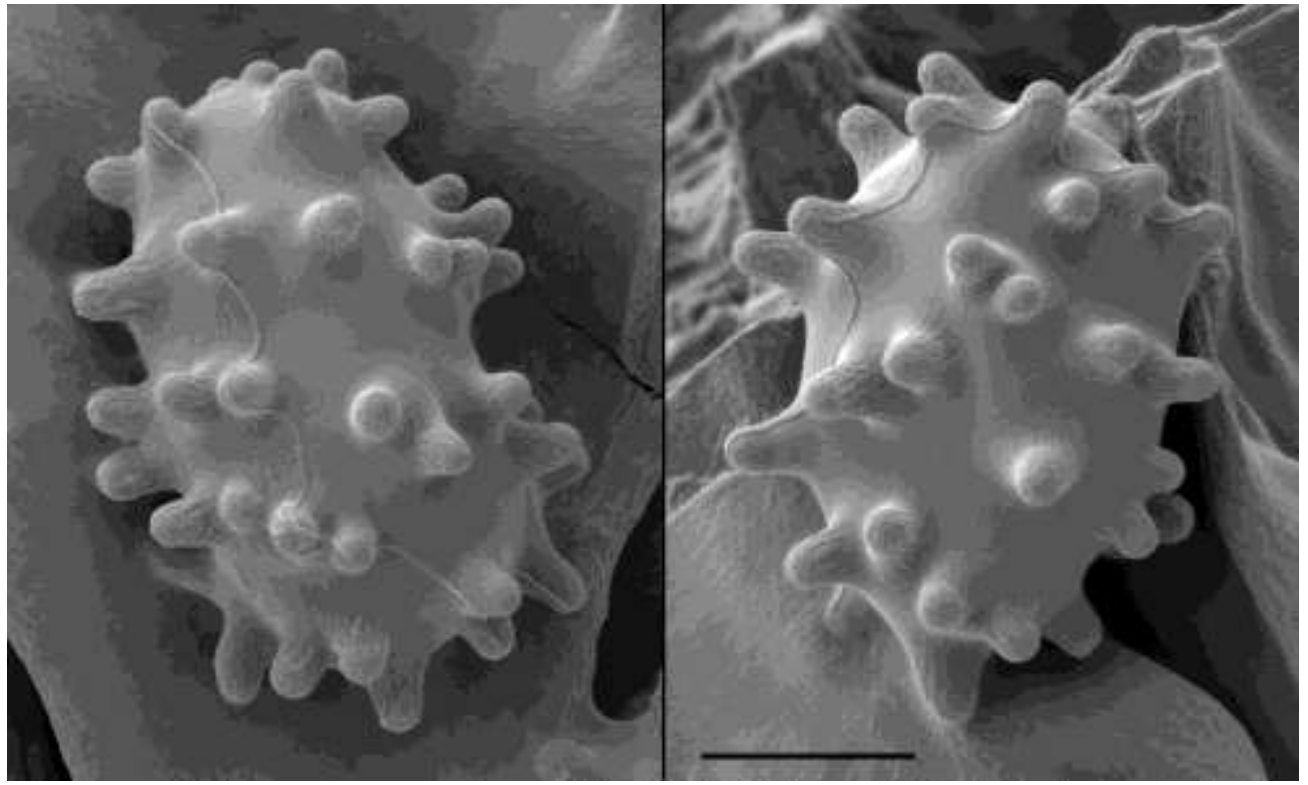

Fig. 2 - Scanning electron micrographs of basidiospores of Scytinopogon havencampii (DED8300). Scale bar $=2 \mu \mathrm{m}$.

Notes - Distinctive features of Scytinopogon havencampii include relatively small, open, densely branched, brittle basidiomes with brown, white-tipped branches arising from a white to pale orangish white stipe, branches that are not flattened, tissues that do not change color when bruised, small, white, coarsely echinate, ellipsoid (not angular) basidiospores with mean $6.1 \times 3.8$ $\mu \mathrm{m}$, short, primarily 2-spored basidia, clamped, non-inflated hyphae 3-8 $\mu \mathrm{m}$ diam, and growth in soil in non-ectotrophic secondary forest on the oceanic island of Príncipe in the Gulf of Guinea,West Africa.

After the exclusion of ambiguously aligned and poorly represented regions, the nLSU data set consists of 830 nucleotides for 27 ingroup taxa and contains 313 variable positions. Three species of Sistotrema and two species of Repetobasidium (Polyporales) were used as outgroup taxa for rooting purposes. Maximum likelihood analyses produced a single topology (Fig. 3). Bayesian analyses reached a split deviation frequency below 0.01 after 1.5 million generations, and the first 1875 trees were excluded as the burn-in. Scytinopogon havencampii is resolved as sister to Scytinopogon angulisporus with 92\% maximum likelihood BS and 1.0 Bayesian posterior probability (PP) support. Both species of Scytinopogon sampled are embedded within the genus Trechispora, but with limited support values (80\% BS and $<0.70 \mathrm{PP})$. Other genera of Trechisporales represented by more than a single taxon, including Brevicellicium, Subulicystidium, Sistotremastrum and Tubulicium are all well-supported as monophyletic (>95\% BS and $1.0 \mathrm{PP}$ ). Constrained topology analyses (data not shown) fail to recover any trees that are significantly more likely than the unconstrained topology. Comparison of the $S$. havencampii ITS sequence using BLAST indicates highest overall identity $(86 \%)$ to three undetermined species of Scytinopogon currently represented in GenBank. 


\section{Discussion}

Most known Scytinopogon species form white to cream basidiomes with flattened branches, and a rather tough texture. Only two species are known to form pigmented basidiomes. Scytinopogon havencampii shows strongest phenetic similarity to $S$. robustus (Rick) Corner, a species described from Brazil and subsequently reported from Puerto Rico, but the latter has pale grey to grayish violet, flattened branches with white subulate to palmate tips, angular-ellipsoid basidiospores, 4-spored basidia, and hyphae up to $25 \mu \mathrm{m}$ diam that are constricted at the septa (Corner 1970). Another pigmented species, Scytinopogon echinosporus (Berk. \& Broome) Corner, known from Sri Lanka and Java, differs in pale purple or lilac, often flattened branches with dark violet-brown tips, ellipsoid to angular basidiospores, 4-spored basidia, inflated hyphae (up to 12 $\mu \mathrm{m}$ diam), and basidiomes that dry black.

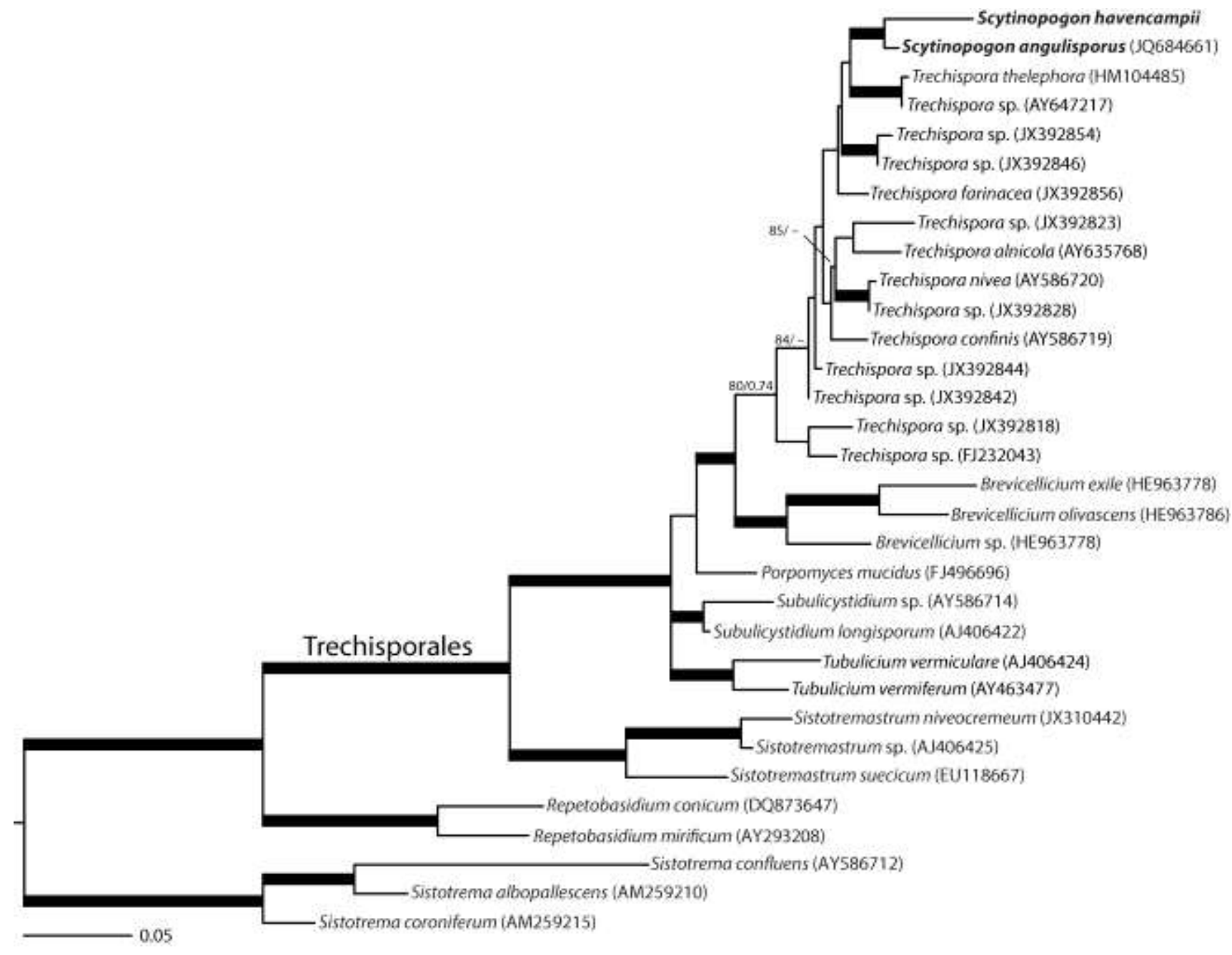

Fig. 3 - Maximum likelihood phylogeny of Trechisporales based on nLSU sequence data. Scytinopogon havencampii and S. angulisporus are indicated in bold type. Values separated by / refer to nonparametric ML bootstrap proportions and Bayesian posterior probabilities. Only values greater than $70 / 0.70$ are shown (- designates a value below $70 \%$ or 0.70 ). Nodes receiving support values greater than 90/0.95 are highlighted in bold.

In a remarkable example of convergence, the new Scytinopogon species is reminiscent of several paleotropical Ramaria taxa, although the latter form ferruginous or ochraceous basidiospores with different ornamentation. Ramaria zippelii (Lév.) Corner, described from material collected in Java (Léveillé 1844) and subsequently reported throughout Indomalaysia (Corner 1950) differs in forming alutaceous, fuliginous-tan or dirty ochraceous basidiomes that 
rapidly turn purplish vinaceous where bruised, usually have a strong paracresol odor, and form larger basidiospores $(10-15 \times 5-8 \mu \mathrm{m})$ on 2-spored basidia. Corner (1950) described $R$. zippellii var. gracilis Corner from material collected in Johore, Malaysia, distinguishing it from the type variety because of smaller and more slender basidiomes, smaller basidiospores 7-10 × 4.5-6.5 $\mu \mathrm{m}$, and basidia that are mostly 3- or 4-spored. Corner (1950) transferred several similar African coralloid species into Ramaria, but with the caveat that they should be compared to Scytinopogon. Ramaria ochracea (Bres.) Corner (type Lachnocladium ochraceum from the DR Congo) forms basidiomes that dry fuscous, lack a stipe, have branches that are ochraceous-pulverulent from basidiospores, and grows on rotten tree trunks (Corner 1950). Ramaria durbana (Van der Byl) Corner (type Clavaria durbana from South Africa) forms smaller $(-25 \times 15 \mathrm{~mm})$, flesh-colored basidiomes, pale ochraceous basidiospores, and grows on wood. The latter species is reported as a synonym of Scytinopogon pallescens in Species Fungorum and MycoBank.

Phylogenetic placement. Jülich (1981) was the first to indicate a relationship between the coralloid Scytinopogon, stipitate-hydnoid Hydnodon and resupinate Trechispora, accepting Scytinopogon in its own family, Scytinopoganaceae Jülich, Hydnodon and Trechispora in the Hydnodontaceae Jülich, and together placing them in the order Hydnodontales Jülich. Based on similar micromorphology, Ryvarden (2002) transferred Hydnodon thelephorus (Lév.) Banker into Trechispora. Molecular data support numerous Trechispora species (Larsson et al. 2004, Telleria et al. 2013), the monotypic Hydnodon (Larsson et al. 2011), the genera Brevicellicium, Subulicystidium, Porpomyces, Sistotremastrum (Larsson 2007, Telleria et al. 2013), Tubulicium and Scytinopogon angulisporus (Pat.) Corner (Birkebak et al. 2013) in a monophyletic lineage dubbed the trechisporoid clade, sister to the Polyporales. The ordinal name Trechisporales K.H. Larsson (in Hibbett et al. 2007) was established for the trechisporoid clade, even though the earlier valid and legitimate Hydnodontales was available (ICN Art. 11.10 - "the principle of priority does not apply above the rank of family"). Birkebak et al. (2013) reported that nLSU sequences of Scytinopogon angulisporus, a species described from Venezuela, clustered within the genus Trechispora. Our results agree with recent molecular analyses of Trechisporales (Birkebak et al. 2013; Telleria et al. 2013) and further suggest a close, yet poorly resolved, phylogenetic placement of Scytinopogon within the genus Trechispora. Constrained analyses forcing both sampled species of Scytinopogon out of a monophyletic Trechispora fail to recover significantly improved tree topologies, suggesting uncertain placement of Scytinopogon based on the current sampling. The type species of Scytinopogon, S. pallescens (Bres.) Singer, described from the DR Congo, has not been sequenced, but has been recognized as a synonym of $S$. angulisporus (described from Venezuela) by Corner (1950) and Petersen (1988). Species Fungorum reports S. pallescens as a distinct species. The type species of Trechispora, T. onusta P. Karst (type locality Finland), has apparently not been sequenced and is not included in any published phylogenies. The coralloid genus Scytinopogon should not be accepted as a synonym of the resupinate Trechispora until the type species of both genera are sequenced and compared.

\section{Acknowledgments}

Foremost we thank Dr. Robert C. Drewes who continues to initiate, coordinate and lead multiorganism biotic surveys on São Tomé and Príncipe. We thank Eng. Arlindo de Ceita Carvalho, Director General of the Ministry of Environment, Victor Bonfim, Salvador Sousa Pontes and Danilo Barbero for permission to collect and export specimens for study. We are indebted to Société de Conservation et Développement for logistics and housing support, especially the wonderful staffs of Omali Lodge and Bom Bom Island. We are grateful for the support and cooperation of Bastien Loloumb of Zuntabawe and Faustino Oliviera, former Director of the botanical garden at Bom Sucesso. We were assisted in the field by Jose Ramos Maria Vital Pires on Príncipe and by Quintino Quade Cabral, Martinho Nascimiento and Jose Clara on São Tomé. For continuing support, we are most grateful to Ned Seligman, Quintino Quade Cabral and Roberta dos Santos of STePUP. We thank Dr. Clive Hayzelden, Director of the SFSU Electron Microscopy Facility, for providing the FE-SEM micrographs. We are grateful to the College of Science and 
Engineering at San Francisco State University for partial funding to support travel to São Tomé and Príncipe, and to the G. Lindsay Field Research Fund of the California Academy of Sciences (CAS) for financially supporting the expedition in 2006 and the Hagey Research Venture Fund (CAS) in 2008. We gratefully acknowledge use of the Carl Zeiss Ultra 55 FE-SEM and supporting equipment at SF State. The FE-SEM and supporting facilities were obtained under NSF-MRI award \#0821619 and NSF-EAR award \#0949176, respectively.

\section{References}

Birkebak JM, Mayor JR, Ryberg KM, Matheny PB. 2013 - A systematic, morphological and ecological overview of the Clavariaceae (Agaricales). Mycologia 105(4), 896-911.

Bresadola G, Roumeguère, C. 1890 - Nouvelles contributions à la Flore mycologique des Iles Saint-Thomé et des Princes, recuilles par MM. Ad, F. Moller, F. Quintas, et F. Newton. Revue Mycologique, Toulouse 12(45), 25-40.

Carlquist S. 1965 - Island Life - A Natural History of the Islands of the World. Natural History Press, New York. 451 p.

Corner EJH. 1950 - A Monograph of Clavaria and Allied Genera. Oxford University Press, London, UK.

Corner EJH. 1966 - Clavarioid genera and Thelephora from the Congo. Bulletin du Jardin Botanique de l'Etat a Bruxelles 36(3), 257-279.

Corner EJH. 1970 - Supplement to "A Monograph of Clavaria and Allied Genera". Beiheft Nova Hedwigia 33, 1-299.

Darriba D, Taboada GL, Doallo R, Posada D. 2012 - jModelTest 2: more models, new heuristics and parallel computing. Nature Methods 9(8), 772.

Desjardin DE, Perry BA. 2009 - A new species of Phallus from São Tomé, Africa. Mycologia 101(4), 543-545.

Douanla-Meli CM. 2007 - Fungi of Cameroon. Bibliotheca Mycologica 202, 1-410.

Gardes M, Bruns TD. 1993 - ITS primers with enhanced specificity for basidiomycetes application to the identification of mycorrhizae and rusts. Molecular Ecology 2, 113-118.

Guindon S, Gascuel O. 2003 - A simple, fast and accurate method to estimate large phylogenies by maximum-likelihood". Systematic Biology 52, 696-704.

Hibbett DS, et al. 2007. A higher-level phylogenetic classification of the Fungi. Mycological Research 111(5), 509-547.

Jülich W. 1981 - Higher taxa of Basidiomycetes. Bibliotheca Mycologica 85, 1-485.

Kornerup A, Wanscher JH. 1978 - Methuen Handbook of Colour. 3rd ed. Eyre Methuen, London.

Larkin MA, Blackshields G, Brown NP, Chenna R, McGettigan PA, McWilliam H, Valentin F, Wallace IM, Wilm A, Lopez R, Thompson JD, Gibson TJ, Higgins DG. 2007 - Clustal W and Clustal X version 2.0. Bioinformatics, 23, 2947-2948.

Larsson K-H. 2007 - Re-thinking the classification of corticioid fungi. Mycological Research 111(9), 1040-1063.

Larsson K-H, Larsson E, Kõljalg U. 2004 - High phylogenetic diversity among corticioid homobasidiomycetes. Mycological Research 108(9), 983-1002.

Larsson K-H, Laessoe T, Nourou S, Ryvarden L. 2011 - The phylogenetic position of Hydnodon and Scytinopogon. Inoculum 62(3), 28.

Lee DC, Halliday AN, Fitton JG, Poli G. 1994 - Isotopic variations with distance and time in the volcanic islands of the Cameroon Line: evidence for a mantle plume origin. Earth and Planetary Science Letters 123, 119-138.

Léveillé JH. 1844 - Champignons exotiques. Annales des Sciences Naturelles Botanique, Series 3, Vol 2, 167-221.

MacArthur RH, Wilson EO. 1967 - The Theory of Island Biogeography. Princeton University Press, New Jersey. 203 p.

Maddison WP, Maddison DR. 2015 - Mesquite: a modular system for evolutionary analysis. 
Version $3.03 \mathrm{http}: / /$ mesquiteproject.org

Miller MA, Pfeiffer W, Schwartz T. 2010 - Creating the CIPRES Science Gateway for inference of large phylogenetic trees. In: Proceedings of the Gateway Computing Environments Workshop (GCE), 14 Nov. 2010, New Orleans, LA, pp 1-8.

Moncalvo JM, Lutzoni FM, Rehner SA, Johnson J, Vilgalys R. 2000 - Phylogenetic relationships of agaric fungi based on nuclear large subunit ribosomal DNA sequences. Systematic Biology 49, 278-305.

Perry BA, Hansen K, Pfister DH. 2007 - A phylogenetic overview of the family Pyronemataceae (Ascomycota, Pezizales). Mycological Research 111, 549-571.

Petersen RH. 1988 - The Clavarioid Fungi of New Zealand. Wellington: DSIR Bulletin 236. 170 p.

Roberts P. 1999 - Clavarioid fungi from Korup National Park, Cameroon. Kew Bulletin 54, 517 539.

Ronquist F, Teslenko M, van der Mark P, Ayres DL, Darling A, Höhna S, Larget B, Liu L, Suchard MA, Huelsenbeck JP. 2012 - MrBayes 3.2: Efficient Bayesian phylogenetic inference and model choice across a large model space. Systematic Biology 61(3), 539-542.

Ryvarden 1. 2002 - A note on the genus Hydnodon Banker. Synopsis Fungorum 15, 31-33.

Shimodaira H, Hasegawa M. 1999 - Multiple comparisons of log-likelihoods with applications to phylogenetic inference. Molecular Biology and Evolution 16, 1114-1116.

Stamatakis A. 2014 - RAxML Version 8: A tool for Phylogenetic Analysis and Post-Analysis of Large Phylogenies. Bioinformatics 10.1093/bioinformatics/btu033

Swofford DL. 2003 - PAUP*. Phylogenetic analysis using parsimony (*and other methods). Version 4. Sinauer Associates, Sunderland, Massachusetts.

Telleria MT, Melo I, Dueñas M, Larsson K-H, Paz Martín MP. 2013 - Molecular analyses confirm Brevicellicium in Trechisporales. IMA Fungus 4(1), 21-28.

White TJ, Bruns T, Lee S, Taylor J. 1990 - Amplification and direct sequencing of fungal ribosomal RNA genes for phylogenetics. In: Innis MA, Gelfand DH, Sninsky JJ, White TJ, eds. PCR Protocols: a guide to methods and applications. Academic Press. San Diego, pp 315-322.

Zwickl DJ. 2006 - Genetic algorithm approaches for the phylogenetic analysis of large biological sequence datasets under the maximum likelihood criterion. Ph.D. dissertation, The University of Texas at Austin. 